\title{
Toplinska svojstva biorazgradljivih mješavina PLA/TPS
}

DOI: 10.15255/KUI.2018.011

$\mathrm{KUI}-43 / 2018$

Prispjelo 10. travnja 2018.

Prihvaćeno 27. lipnja 2018.

\author{
V. Ocelić Bulatović,a, E. Govorčin Bajsić,a D. Kučić Grgića i A. Jozinovićb \\ a Sveučilište u Zagrebu, Fakultet kemijskog inženjerstva i tehnologije, \\ Marulićev trg 19, 10000 Zagreb \\ bSveučilište Josipa Jurja Strossmayera u Osijeku, Prehrambeno-tehnološki fakultet, \\ Franje Kuhača 20, 31000 Osijek
}

Ovo djelo je dano na korištenje pod Creative Commons Attribution 4.0 International License

\begin{abstract}
Sažetak
U ovom radu ispitana su toplinska svojstva mješavina različitog udjela polilaktida (PLA) i termoplastičnog škroba (TPS). TPS je pripremljen s različitim udjelima glicerola (30 i 40 mas. \%) kao plastifikatora. Radi uvida u hidrofilni/hidrofobni karakter mješavina PLA/TPS praćena je apsorpcija vode. Rezultati toplinskih svojstava pokazali su da TPS ubrzava proces hladne kristalizacije polilaktida uslijed nukleacijskog učinka TPS-a. TPS povećava sposobnost kristalizacije PLA i omogućava pravilnije slaganje lanaca polilaktida u kristalnoj strukturi. Utjecaj glicerola kao plastifikatora TPS-a nema značajnu ulogu u ispitivanju toplinskih svojstava, dok je ispitivanje apsorpcije vode pokazalo da se uz veći udio glicerola kao plastifikatora TPS-a dobivaju niže vrijednosti apsorpcije vode mješavina PLA/TPS.
\end{abstract}

\section{Ključne riječi}

Polilaktid, termoplastični škrob, plastifikacija, glicerol, toplinska svojstva, apsorpcija vode

\section{Uvod}

S obzirom na sve veći problem odlaganja sintetskih polimera koji su otporni na kemijsku i biološku razgradnju, važnost biorazgradljivih polimera znatno je u porastu. Najveća prednost uporabe biorazgradljivih polimera je smanjenje količine plastičnog otpada s obzirom na to da oni podliježu razgradnji djelovanjem bioloških čimbenika. Veća pažnja pridaje se prirodnim biorazgradljivim polimernim materijalima s obzirom na to da se oni baziraju na obnovljivim izvorima, odnosno dobivaju se iz prirodnih izvora ili sintezom monomera prirodnog podrijetla. Primjeri takvih polimera su polisaharidi (škrob, celuloza), proteini (vuna, svila), lipidi (masti, ulja), poliesteri koje proizvode biljke ili mikroorganizmi (polihidroksi alkaloati, PHA), poliesteri koji se dobivaju iz bio-izvedenih monomera (polilaktid, PLA). ${ }^{1}$ No, osim spomenute prednosti biorazgradnje, postoje razni nedostatci biorazgradljivih polimernih materijala koje je potrebno prevladati za njihovu širu uporabu. Biorazgradljivi polimerni materijali pokazuju lošija svojstva od sintetskih polimernih materijala. Jedan od nedostataka je niska čvrstoća i toplinska stabilnost, a velik je problem visoka cijena te zahtjevnost procesa njihove pripreme. Kako bi se nadvladali ti nedostatci, sve se više paž- nje pridaje pokušajima modifikacije strukture biorazgradljivih polimera u svrhu dobivanja zadovoljavajućih svojstava ili pripremi biorazgradljivih polimernih mješavina koje će posjedovati željena svojstva važna za primjenu. ${ }^{2}$ Jedan od obećavajućih materijala među biorazgradljivim polimerima smatra se polilaktid, koji se ističe dobrim mehaničkim svojstvima (visoka čvrstoća), biokompatibilnošću te je relativno dostupan. ${ }^{3-6}$ PLA je biorazgradljiv termoplastični poliester koji se dobiva iz obnovljivih izvora kao što su kukuruz i šećerna trska, te je stoga intenzivno istraživan tijekom posljednjih nekoliko desetljeća. Fermentacijom ugljikohidrata prirodnog podrijetla dobiva se mliječna kiselina, koja je osnovna konstitucijska jedinica PLA. PLA može postojati u tri stereokemijska oblika: poli (L-laktid) (PLLA), poli (Dlaktid) (PDLA) i poli (DL-laktid) (PDLLA). ${ }^{4,5}$

U odnosu na druge biorazgradljive polimere kao što su poli (hidroksi alkanoati) (PHA), poli (etilen glikol) (PEG), poli ( $\varepsilon$-kaprolakton) (PCL) i sl., PLA se odlikuje boljom toplinskom preradljivošću. Može se preraditi injekcijskim prešanjem, ekstruzijom filma, puhanjem, termoformiranjem, predenjem vlakana i formiranjem filma. lako je PLA ekološki prihvatljiv s odličnom biokompatibilnošću i preradljivošću, izrazito visoka cijena ograničava njegovu primjenu. ${ }^{3}$

\footnotetext{
* Autor za dopisivanje: dr. sc. Vesna Ocelić Bulatović e-pošta:vocelic@fkit.hr
} 
Moguća alternativa za prevladavanje nedostatka visoke cijene je miješanje $s$ termoplastičnim škrobom (TPS). ${ }^{7}$ Opće je poznato da je miješanje polimera najisplativiji način za dobivanje materijala s traženim svojstvima. Škrob ima velik potencijal kao sirovina za biorazgradljive polimere zbog svoje prirodne biorazgradljivosti, iznimno niske cijene i široke dostupnosti. ${ }^{8,9} \mathrm{~S}$ kemijskog aspekta, škrob se sastoji od dva osnovna polisaharida, amiloze i amilopektina i manjeg udjela komponenata kao što su lipidi i proteini. Amiloza je u osnovi linearna molekula ( $1 \rightarrow 4)$, u kojoj su jedinice glukoze povezane $\alpha$-D-glukopiranozilnim jedinicama djelomično razgranate strukture $\mathrm{s}(1 \rightarrow 6)-\alpha$-vezama. Amilopektin je razgranata molekula koja se sastoji od lanaca $\alpha$-D-glukopiranozilnih ostataka povezanih uglavnom $(1 \rightarrow 4)$-vezama, ali s $(1 \rightarrow 6)$-vezama na mjestu grananja. ${ }^{10-12}$ Po svojoj prirodi škrob nije tipičan termoplastični polimerni materijal. Budući da je temperatura taljenja $\left(T_{\mathrm{m}}\right)$ prirodnog suhog škroba između 220 i $240{ }^{\circ} \mathrm{C}$, a početak temperature razgradnje škroba je oko $220^{\circ} \mathrm{C}$, prirodni škrob potrebno je modificirati kako bi se mogao prerađivati kao termoplastični polimerni materijal. ${ }^{10}$ Transformacija prirodnog škroba u termoplastični polimerni materijal uključuje ireverzibilan sređeno-nesređeni prijelaz koji se naziva plastificiranje. Termoplastični škrob je plastificirani škrob koji se obrađuje (obično zagrijavanjem i pod tlakom) kako bi se potpuno razorila kristalna struktura škroba i dobio amorfni termoplastični škrob. ${ }^{13,14}$ Plastificiranje škroba predstavlja razrušavanje molekulske strukture škroba interakcijom škroba i vode. Pojednostavljeni proces plastifikacije prikazan je na slici 1. Škrob se sastoji od amiloze (linearne) i amilopektina (razgranate) molekule (stupanj (a)). Dodatkom vode narušava se kristalnost amiloze kao i razrušavanje heliksa (spirala). Dolazi do bubrenja škroba (stupanj (b)). Dodatnim zagrijavanjem uz suvišak vode dolazi do bubrenja i amiloza izlazi iz škroba (stupanj (c)). Škrob uglavnom sadrži amilopektin koji se raspada i drži u matrici amiloze (stupanj (d)). ${ }^{11}$ Voda je uobičajeno plastifikator, no zbog svoje nestabilnosti pri visokim temperaturama prikladniji su organski tekući plastifikatori. Molekule kao što su poliglikoli (npr. glicerol, sorbitol, itd.), amidi i amini djeluju kao nehlapljiva omekšavala za škrob. ${ }^{11}$ Stoga je pogodniji način dobivanja termoplastičnog škroba dodatkom plastifikatora u ekstruder bez dodatka vode. $U$ ekstruderu se škrob dobiva primjenom toplinske i mehaničke energije, pri čemu se javljaju tri osnovna fenomena na različitim strukturnim razinama: fragmentacija granula škroba; cijepanje vodikove veze između molekula škroba, što rezultira sniženjem kristalnosti; i parcijalne depolimerizacije polimera škroba. Nadalje, proces ekstrudiranja osigurava dobro miješanje polimera i aditiva. Uvođenjem mehaničke energije i topline u temperaturnom području $120-220^{\circ} \mathrm{C}$, kristalni škrob se homogenizira i tali tijekom ekstruzije s plastifikatorom koji snižava temperaturu taljenja škroba. Tim procesom provodi se konačna konverzija molekulske strukture termoplastičnog škroba, i time termoplastični škrob ne sadrži kristalne frakcije. Jaki hidrofilni karakter i slaba mehanička svojstva u usporedbi s konvencionalnim sintetskim polimerima najznačajniji su nedostatci škroba koji ga čine nezadovoljavajućim za neke primjene kao u slučaju pakiranje hrane. S druge strane, važna svojstva termoplastičnih materijala na osnovi škroba uključuju mogućnost kompostiranja, visoku propusnost vodene pare, dobra barijerna svojstva, smanjenje statičkog elektriciteta te nisku toplinsku stabilnost. ${ }^{10-14}$

Cilj ovoga rada bio je istražiti toplinska svojstava biorazgradljivih polimera, polilaktida (PLA) i termoplastičnog škroba (TPS) pripremljenog s različitim udjelom glicerola kao plastifikatorom. Toplinska svojstva određena su primjenom diferencijalne pretražne kalorimetrije (DSC) i termogravimetrijske analize (TGA) te, s obzirom na hidrofilni karakter TPS-a, suprotno njemu hidrofoban karakter PLA, ispitana je apsorpcija vode mješavina PLA/TPS.

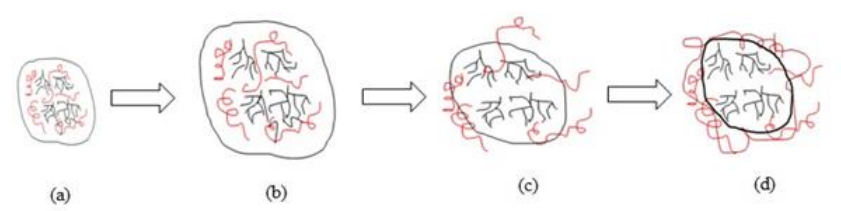

Slika 1 - Proces plastificiranja škroba

Fig. 1 - Plastification process of starch

\section{Eksperimentalni dio}

\subsection{Materijali}

$U$ radu je je uporabljen prirodni škrob pšenice izoliran iz sorte pšenice "Srpanjka", darovane od Poljoprivrednog instituta Osijek (žetva 2008.godine). Za plastificiranje prirodnog pšeničnog škroba uporabljen je redestilirani glicerol, proizvođača Gram Mol, Zagreb, Hrvatska.

Uporabljen je polilaktid, PLA komercijalnog naziva Ingeo ${ }^{\text {TM }}$ Biopolymer, šifra proizvoda 4043D, proizvođača Nature Works LLC, USA. Prema podatcima proizvođača gustoća polimera je $1,24 \mathrm{~g} \mathrm{~cm}^{-3}$, staklište je između 50 i $70{ }^{\circ} \mathrm{C}$, a talište $145-160^{\circ} \mathrm{C}$.

\subsection{Priprema uzoraka}

Prirodni pšenični škrob plastificiran je procesom ekstruzije s udjelom od 30 mas. \% i 40 mas. \% redestiliranog glicerola. Postupak ekstruzije proveden je na laboratorijskom jednopužnom ekstruderu Brabender 19/20 DN, pri sljedećim uvjetima ekstruzije: puž konfiguracije: $1: 1$; sapnica promjera: $4 \mathrm{~mm}$ uz temperaturni profil: $100 / 100 / 130{ }^{\circ} \mathrm{C}$ (prva/druga/treća zona zagrijavanja) pri brzini vrtnje puža ekstrudera od $40 \mathrm{o} \mathrm{min}^{-1} \mathrm{i}$ brzinom dozirke od $15 \mathrm{o} \mathrm{min}^{-1}$.

Polimerne mješavine pripravljene su u Brabender gnjetelici zamješavanjem polilaktida $\mathrm{s}$ različitim udjelom termoplastičnog škroba na temperaturi od $170{ }^{\circ} \mathrm{C}$ pri 60 o min $^{-1} \mathrm{u}$ vremenu od 5 min da bi se osigurala dobra dispergiranost 
termoplastičnog škroba u PLA. Ispitna tijela za daljnju karakterizaciju dobivena su prešanjem granula u kalupu pri temperaturi od $180{ }^{\circ} \mathrm{C}$, na hidrauličkoj preši Fontune, Holland (SRB 140, EC 320x320NB). Postupak prešanja proveden je na $180{ }^{\circ} \mathrm{C}$ predgrijavanjem materijala od 2 min i daljnjim zagrijavanjem od 5 min pri tlaku od 25 bar nakon čega je provedeno hlađenje vodom na $40{ }^{\circ} \mathrm{C}$. Dimenzije dobivenih ispitnih tijela iznosile su $100 \times 100 \times 1 \mathrm{~mm}$. U tablici 1 prikazan je sastav pripremljenih mješavina i njihove oznake.

Tablica 1 - Sastav ispitivanih mješavina

Table 1 - Composition of the investigated samples

\begin{tabular}{|c|c|c|c|}
\hline $\begin{array}{l}\text { Uzorak } \\
\text { Sample }\end{array}$ & $\begin{array}{c}\text { PLA/mas. \% } \\
\text { / wt. \% }\end{array}$ & $\begin{array}{c}\text { TPS }_{30} / \text { mas. } \% \\
\text { /wt. } \%\end{array}$ & $\begin{array}{c}\text { TPS }_{40} / \text { mas. } \% \\
\text { / wt. \% }\end{array}$ \\
\hline PLA & 100 & - & - \\
\hline $\mathrm{TPS}_{30}$ & - & 100 & - \\
\hline $\mathrm{TPS}_{40}$ & - & - & 100 \\
\hline $\mathrm{PLA} / \mathrm{TPS}_{30} 60 / 40$ & 60 & 40 & - \\
\hline $\mathrm{PLA} \mathrm{TPS}_{40} 60 / 40$ & 60 & - & 40 \\
\hline $\mathrm{PLA} \mathrm{TPS}_{30}$ 50/50 & 50 & 50 & - \\
\hline $\mathrm{PLA} \mathrm{TPS}_{40}$ 50/50 & 50 & - & 50 \\
\hline $\mathrm{PLA} / \mathrm{TPS}_{30} 40 / 60$ & 40 & 60 & - \\
\hline $\mathrm{PLA} \mathrm{TPS}_{40} 40 / 60$ & 40 & - & 60 \\
\hline
\end{tabular}

\subsection{Karakterizacija}

\subsubsection{Toplinska svojstva - DSC analiza}

Toplinska svojstva uzoraka pri neizotermnim uvjetima određena su diferencijalnom pretražnom kalorimetrijom (DSC), na instrumentu DSC 823 e Mettler Toledo. Uređaj je kalibriran testom taljenja indija kojem je poznata vrijednost temperature i entalpije taljenja. Uzorci mase od oko 10 mg stavljeni su u aluminijske posudice i hermetički zatvoreni. Uzorci su najprije zagrijavani od sobne temperature do $200{ }^{\circ} \mathrm{C}$, brzinom zagrijavanja od $10{ }^{\circ} \mathrm{Cmin}^{-1}$, kako bi se izbrisala njihova toplinska povijest tj. uklonjena su sva potencijalna zaostala naprezanja i nepravilnosti nastale prilikom preradbe polimera. Nakon izotermne stabilizacije pri $200{ }^{\circ} \mathrm{C}$ u trajanju od $2 \mathrm{~min}$, provedeno je hlađenje od $200{ }^{\circ} \mathrm{C}$ do $-80{ }^{\circ} \mathrm{C}$ brzinom $10^{\circ} \mathrm{C} \mathrm{min}^{-1}$, pri čemu je praćena kristalizacija uzorka. Nakon izotermne stabilizacije pri $-80{ }^{\circ} \mathrm{C}$ u trajanju od 2 min uzorak je ponovno zagrijavan od $-80{ }^{\circ} \mathrm{C}$ do $200{ }^{\circ} \mathrm{C}$ brzinom $10{ }^{\circ} \mathrm{Cmin}^{-1}$, pri čemu je praćen proces hladne kristalizacije i taljenja nastale kristalne faze. Mjerenja su provedena u struji dušika uz protok $50 \mathrm{ml} \mathrm{min}^{-1}$.

Stupanj kristalnosti PLA $\left(\chi_{c}\right)$ izračunat je na osnovi vrijednosti $\Delta H_{\mathrm{m}}{ }^{0}\left(\mathrm{Jg}^{-1}\right)$ dobivenih iz mjerenja DSC-om preko iz$\operatorname{raza}(1):^{7}$

$$
\chi_{\mathrm{c}}(\%)=\frac{\Delta H_{\mathrm{m}}}{\Delta H_{\mathrm{m}}^{0} \cdot w(\mathrm{PLA})} \cdot 100
$$

gdje je $\Delta H_{\mathrm{m}}{ }^{0}\left(\mathrm{Jg}^{-1}\right)$ specifična entalpija taljenja dobivena mjerenjem DSC-om, $\Delta H_{\mathrm{m}}{ }^{0}\left(\mathrm{~J} \mathrm{~g}^{-1}\right)$ specifična entalpija taljenja za $100 \%$ kristalan PLA i iznosi 93,7 J g ${ }^{-1}$, te $w(P L A)$ je maseni udio PLA u ispitivanom uzorku. ${ }^{15}$ DSC analizom dobiveni su termogrami, gdje su entalpijske promjene prikazane kao maksimum ili minimum na krivulji. Iz entalpijske promjene pri taljenju ili kristalizaciji određeno je talište odnosno kristalište i to kao temperatura u maksimumu krivulje. Topline taljenja i topline kristalizacije predstavljaju površina ispod pika taljenja, kristalizacije i izravna su mjera entalpije taljenja, odnosno entalpije kristalizacije $\left(\Delta H_{\mathrm{m}}\right.$; $\left.\Delta H_{\mathrm{c}}\right)$.

\subsubsection{Toplinska stabilnost - TGA analiza}

Toplinska stabilnost uzoraka ispitana je termogravimetrijskom analizom, TGA, na uređaju TA Instruments Q500. Kontinuiranim mjerenjem promjene mase uzorka u funkciji temperature određen je početak i kraj razgradnje materijala. Mjerenje je provedeno pri brzini zagrijavanja od $10{ }^{\circ} \mathrm{C}$ min $^{-1}$ u temperaturnom području od $25^{\circ} \mathrm{C}$ do $600{ }^{\circ} \mathrm{C}$. Uzorci mase oko $10 \mathrm{mg}$ zagrijavani su u otvorenoj platinskoj posudici u inertnoj atmosferi dušika uz protok $60 \mathrm{ml} \mathrm{min}{ }^{-1}$. Rezultati su prikazani TG krivuljom koja predstavlja promjenu mase uzorka u ovisnosti o temperaturi, a deriviranjem dobivene krivulje dobivena je ovisnost brzine promjene mase o temperaturi, tzv. derivativna krivulja, DTG.

\subsubsection{Apsorpcija vode, AV}

Apsorpcija vode određena je na uzorcima pravokutnog oblika dimenzija $2 \mathrm{~cm} \times 1 \mathrm{~cm}$. Prije samog mjerenja uzorci su sušeni $24 \mathrm{~h}$ pri $105{ }^{\circ} \mathrm{C}$ kako bi se uklonila vezana voda. Ispitivani uzorci su izvagani i dobivena je njihova početna masa, $m_{0}$. Zatim su uronjeni u Petrijeve zdjelice s destiliranom vodom (na $25^{\circ} \mathrm{C}$ ) kako bi se pratila apsorpcija vode tijekom pet dana. Svaka $24 \mathrm{~h}$ uzorci su izvađeni iz vode, lagano osušeni ubrusom da bi se uklonila zaostala voda na površini uzorka te vagani $\left(m_{1}\right)$, potom su vraćeni u vodu radi daljnjeg praćenja apsorpcije vode. Apsorpcija vode, $A V$, izračunata je prema izrazu (2):

$$
A V(\%)=\frac{m_{1}-m_{0}}{m_{0}} \times 100
$$




\section{Rezultati i rasprava}

\subsection{Toplinska svojstva - DSC analiza}

Toplinska svojstva čistog PLA i mješavina PLA/TPS s TPSom različitog udjela glicerola kao plastifikatora istražena su DSC analizom u neizotermnim uvjetima. Iz dobivenih DSC-ovih termograma određeni su fazni prijelazi: temperatura staklastog prijelaza $\left(T_{\mathrm{g}}\right)$, temperatura taljenja $\left(T_{\mathrm{m}}\right)$, temperatura hladne kristalizacije $\left(T_{\text {cc }}\right)$ te je izračunat stupanj kristalnosti $\left(\chi_{c}\right)$. Navedeni fazni prijelazi, entalpije hladne kristalizacije i entalpije taljenja $\left(\Delta H_{c c} \Delta H_{\mathrm{m}}\right)$ određeni su iz drugog ciklusa zagrijavanja. Rezultati DSC analize odnosno normirane krivulje zagrijavanja DSC i hlađenja PLA te polimernih mješavina PLA/TPS prikazani su na slikam 25 , te su karakteristične vrijednosti dobivene iz DSC krivulja sumarno prikazane u tablici 2. Na slikama 2 i 3 vidljivo je izražena temperatura staklastog prijelaza $\left(T_{\mathrm{g}}\right)$ čistog PLA pri $60{ }^{\circ} \mathrm{C}$. Vrijednost $T_{\mathrm{g}}$ ukazuje da se PLA pri sobnoj temperaturi nalazi u staklastom stanju, odnosno da se polimerni lanci nalaze u stanju niže energije pri kojemu skupine samo titraju oko ravnotežnog položaja. Nastavkom zagrijavanja povećava se gibanje makromolekula PLA i one se prestrukturiraju uz oslobađanje energije. Egzotermna promjena na termogramu predstavlja proces hladne kristalizacije s izraženim maksimumom pika, odnosno temperaturom hladne kristalizacije pri $125{ }^{\circ} \mathrm{C}\left(T_{\mathrm{cc}}\right)$, što upućuje na to da u procesu hlađenja pri brzini od $10{ }^{\circ} \mathrm{C} \mathrm{min}{ }^{-1}$ PLA nije potpuno iskristalizirao. ${ }^{16}$ Do hladne kristalizacije dolazi jer nakon staklastog prijelaza molekulski lanci polilaktida imaju dovoljnu fleksibilnost da kristaliziraju. Nakon hladne kristalizacije postiže se temperatura taljenja, odnosno PLA apsorbira toplinu te se molekule počinju slobodno gibati. Ta promjena se na termogramu uočava kao endotermni prijelaz taljenja kristalita nastalih tijekom hladne kristalizacije, $s$ jasno izraženim pikom temperature taljenja pri $152{ }^{\circ} \mathrm{C}\left(T_{\mathrm{m}}\right)$. Kristalasti polimeri poput PLA kristaliziraju tijekom zagrijavanja (hladna kristalizacija) jer imaju sposobnost spore kristalizacije, te nemaju dovoljno vremena kristalizirati tijekom hlađenja. ${ }^{17}$ Dodatkom TPS $_{30}$ i $^{\text {TPS }_{40}}$ dolazi do sniženja $T_{\mathrm{g}}$ PLA za $6{ }^{\circ} \mathrm{C}$ u mješavinama, odnosno $5{ }^{\circ} \mathrm{Cu}$ odnosu na čisti PLA. Sniženje $T_{\mathrm{g}}$ ukazuje na veću mobilnost polimernih lanaca, odnosno na moguće interakcije između PLA i TPS-a, što ukazuje na njihovu međusobnu mješljivost. ${ }^{18}$ Povećanjem udjela TPS-a nisu uočeni značajni pomaci vrijednosti temperature staklastog prijelaza. Pikovi temperature hladne kristalizacije pomiču se na niže vrijednosti dodatkom TPS-a, što ukazuje na to da TPS ubrzava neizotermnu kristalizaciju PLA. Entalpija hladne kristalizacije se značajnije smanjuje pri većem sadržaju dodanog TPS-a. Na krivuljama zagrijavanja mješavina PLA/TPS uočava se pojava dvostrukog pika taljenja, koji se pripisuje polilaktidu, s obzirom na to da je TPS potpuno amorfan polimer. Pojava dvostrukog pika taljenja odnosi se na taljenje malih i nesavršenih kristala tijekom postupka rekristalizacije polilaktida. ${ }^{19-21}$ Višestruki pikovi pri zagrijavanju polilaktida objašnjavaju se preko dva različita pristupa. Prvi pristup povezuje dvostruki pik taljenja PLA s formiranjem različitih kristalnih struktura: $\alpha$-oblik (pseudo-ortoromski ili pseudo-heksagonalni ili ortoromski), koji se tali na višoj temperaturi, i $\beta$-oblik (ortorombski ili trigonalni) koji se tali na nižoj temperaturi. $\alpha$-oblik je najčešći polimorf, dok je pakiranje $\beta$-oblika objašnjeno kao nesavršena kristalna struktura. Međutim, kako spiralne konformacije lanaca u $\alpha$ - i $\beta$-strukturama imaju otprilike istu energiju, pakiranje bi stoga trebalo biti glavni razlog za istodobno postojanje dvije različite kristalne strukture. ${ }^{22}$ Drugi pristup opisuje dvostruki pik taljenja PLA modelom taljenja-rekristalizacije. Prema tom modelu tijekom zagrijavanja povećanjem temperature mali i nesavršeni kristali prelaze u stabilnije kristalne forme mehanizmom taljenja-rekristalizacije. Odnosno, taljenje i kristalizacija se tijekom zagrijavanja odvijaju istodobno. ${ }^{22}$ Općenito, smanjenje temperature taljenja u polimernoj mješavini može biti posljedica morfološkog učinka (smanjenje debljine lamela) i termodinamičkog učinka (polimer-polimer interakcije). ${ }^{23} \mathrm{~S}$ termodinamičkog gledišta, smanjenje temperature taljenja u polimernoj mješavini povezano je sa smanjenjem kemijskog potencijala kristala koji mogu kristalizirati uslijed djelomičnog miješanja s amorfnim polimerom. Ta pretpostavka objašnjava sniženje temperature taljenja mješavina za ispitivane sustave u ovom radu. Sniženje $T_{m}$ dobiveno je kada se kristalasta komponenta PLA pomiješa s amorfnim polimerom (TPS u ispitivanim sustavima). ${ }^{23-25}$ To neznatno sniženje $T_{\mathrm{m}}$ ukazuje na mali stupanj miješanja/kompatibilnosti unutar mješavine. Također se ne može zanemariti utjecaj glicerola na kristalnu fazu PLA. ${ }^{22}$ Općenito, vrijednosti temperatura taljenja upućuju na uređenost kristalne faze, odnosno vrijedi da uređenija kristalna faza ima višu temperaturu taljenja. Temperatura taljenja dodatkom TPS-a pomiče se prema nižim vrijednostima, dok daljnje povećanje udjela TPS-a nema značajnijeg utjecaja na $T_{m}$. Također, sadržaj plastifikatora nema značajan utjecaj na $T_{\mathrm{m}}$. Entalpija taljenja raste dodatkom TPS-a (40\%), dok daljnjim povećanjem TPS-a dolazi do sniženja entalpije taljenja za oba TPS-a. Na slikama 2 i 3 i tablici 2 vidljivo je da se vrijednosti temperatura hladne kristalizacije pomiču prema nižim temperaturama s obzirom na čisti PLA, što ukazuje na to da dolazi do ubrzavanja procesa hladne kristalizacije dodatkom termoplastičnog škroba i nukleacijski učinak TPS-a na PLA. Dodatkom oba termoplastična škroba vidljiv je značajan skok stupnja kristalnosti PLA. Vrijednost stupnja kristalnosti čistog PLA je 18,4\%. Dodatkom većeg udjela TPS-a (50 \%) dolazi do porasta stupnja kristalnosti preko $100 \%$. Prema nekim istraživanjima, TPS može djelovati kao nukleacijski čimbenik (poput punila), čime potiče hladnu kristalizaciju PLA, odnosno dolazi do znatnog porasta stupnja kristalnosti PLA. ${ }^{26}$ To ukazuje da TPS povećava sposobnost kristalizacije PLA te je omogućeno pravilnije slaganje lanaca polilaktida u kristalnoj strukturi. Vidljivo je da pri većem udjelu TPS-a (60\%), stupanj kristalnosti PLA pada u usporedbi s manjim udjelom dodanog TPS-a (50\%), dok u us- 
poredbi s čistim PLA i dalje raste za više od 100 \%. Iz krivulja hlađenja za PLA kao i PLA/TPS (slike 4 i 5) nema vidljivih pikova temperature kristalizacije zbog vrlo karakterističnih osobina PLA, PLA sporo postiže kristalizaciju hlađenjem, u ovom slučaju brzina hlađenja bila je prevelika da bi omogućila kristalizaciju u ispitivanim uzorcima PLA i PLA/TPS-a. ${ }^{23}$

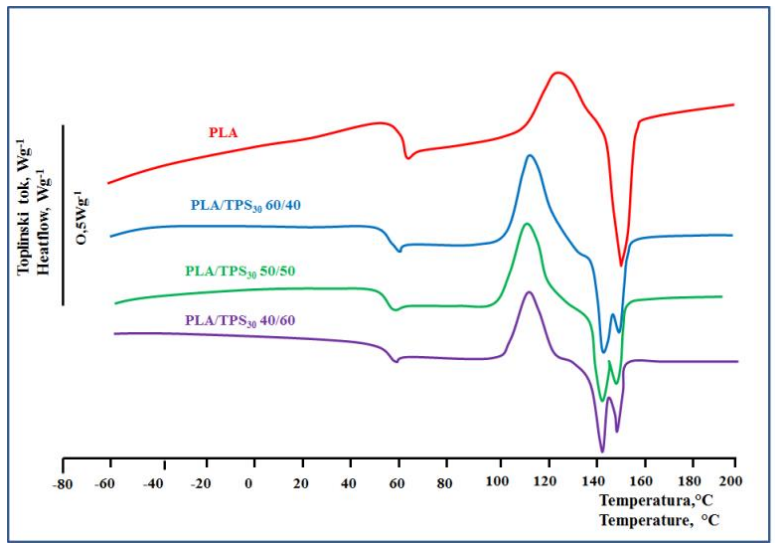

Slika 2 - DSC krivulje zagrijavanja za PLA i mješavine s TPS $_{30}$ Fig. 2 - DSC curves for PLA and its blends with TPS $_{30}$

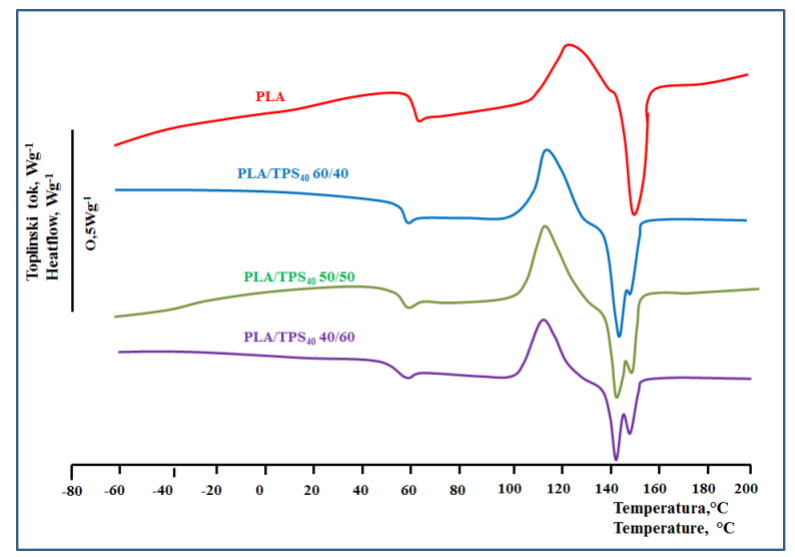

Slika 3 - DSC krivulje zagrijavanja za PLA i mješavine s TPS $_{40}$

Fig. 3 - DSC heating curves for PLA and its blends with $\mathrm{TPS}_{40}$

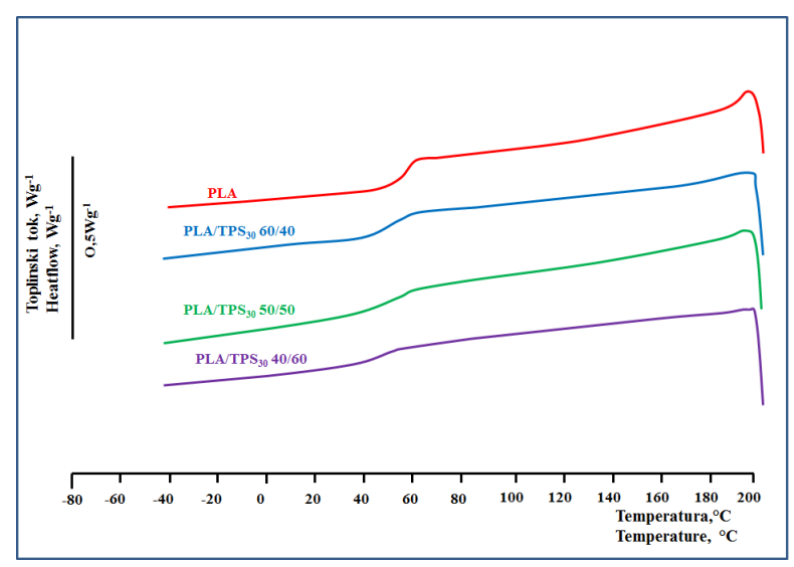

Slika 4 - DSC krivulje hlađenja za PLA i mješavine s TPS30

Fig. 4 - DSC cooling curves for PLA and its blends with TPS30

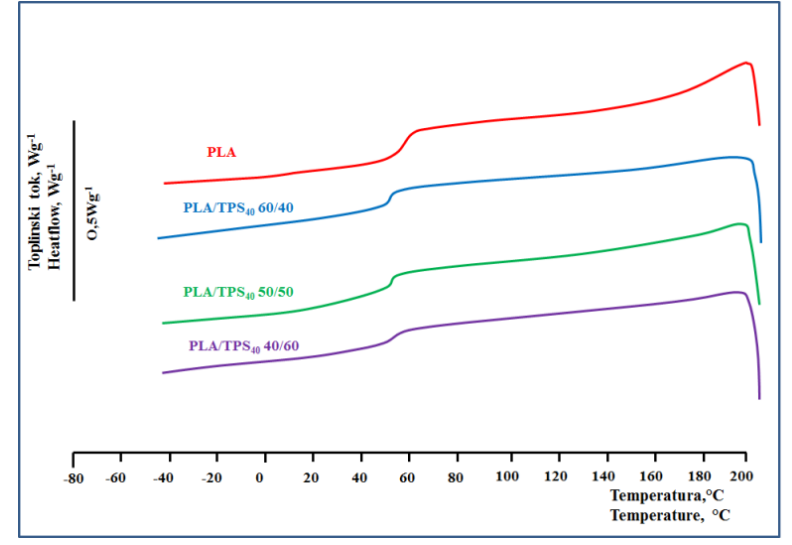

Slika 5 - DSC krivulje hlađenja za PLA i mješavine s TPS $_{40}$

Fig. 5 - DSC cooling curves for PLA and its blends with $\mathrm{TPS}_{40}$

Tablica 2 - Rezultati toplinskih svojstava

Table 2 - Results of thermal properties

\begin{tabular}{|c|c|c|c|c|c|c|}
\hline $\begin{array}{l}\text { Uzorak } \\
\text { Sample }\end{array}$ & $\begin{array}{c}T_{\mathrm{g}} \\
/{ }^{\circ} \mathrm{C}\end{array}$ & $\begin{array}{c}T_{\mathrm{m}} \\
/{ }^{\circ} \mathrm{C}\end{array}$ & $\begin{array}{l}T_{\mathrm{cc}} \\
/{ }^{\circ} \mathrm{C}\end{array}$ & \begin{tabular}{|l|}
$\Delta H_{\mathrm{cc}}$ \\
$/ \mathrm{Jg}^{-1}$
\end{tabular} & \begin{tabular}{|l|}
$\Delta H_{\mathrm{m}}$ \\
$/ \mathrm{Jg}^{-1}$
\end{tabular} & $\begin{array}{l}\chi_{c} \\
/ \%\end{array}$ \\
\hline PLA & 60 & 152 & 125 & 18,3 & 17,2 & 18,4 \\
\hline PLA/TPS 30 60/40 & 54 & 144 & 116 & 18,0 & 18,7 & 33,2 \\
\hline PLA/TPS 40 60/40 & 54 & 144 & 114 & 19,5 & 18,6 & 33,1 \\
\hline PLA/TPS 30 50/50 & 54 & 143 & 112 & 17,6 & 17,4 & 37,1 \\
\hline $\mathrm{PLA} / \mathrm{TPS}_{40}$ 50/50 & 55 & 144 & 115 & 19,1 & 17,1 & 36,5 \\
\hline PLA/TPS 30 40/60 & 54 & 143 & 113 & 13,2 & 13,8 & 36,9 \\
\hline PLA/TPS 40 40/60 & 54 & 144 & 114 & 13,2 & 13,2 & 35,3 \\
\hline
\end{tabular}

\subsection{Toplinska svojstva - TGA analiza}

Termogravimetrijskom analizom istražena je toplinska stabilnost čistog PLA, TPS ${ }_{30}$, TPS $_{40}$ te PLA/TPS 30 i PLA/TPS 40 mješavina različitog udjela pojedinog polimera (tablica 1 ). Dobiveni rezultati prikazani su na slikama 6-10, te sumarno u tablici 3. Iz dobivenih krivulja određene su temperature početka razgradnje $\left(T_{\text {poč. }}\right)$, temperature kraja razgradnje $\left(T_{\text {kraj}}\right)$, temperatura pri maksimalnoj brzini razgradnje $\left(T_{\max }\right)$, s pripadajućim udjelom gubitka mase $(\Delta m)$, područje razgradnje $(\Delta T)$ te ostatak pri $600{ }^{\circ} \mathrm{C}\left(R_{600^{\circ} \mathrm{C}}\right)$. Temperatura početka razgradnje ukazuje na toplinsku stabilnost ispitivanih mješavina i može se razlikovati ovisno o omjeru PLA i TPS-a te udjelu dodanog glicerola kao plastifikatora TPS-a. Na slici 6 prikazane su TG i DTG krivulje čistog PLA, te plastificiranog škroba, TPS, različitog udjela glicerola kao plastifikatora, $\mathrm{TPS}_{30}$ i TPS $\mathrm{TP}_{40}$. Iz dobivenih krivulja vidljivo je da se toplinska razgradnja PLA odvija u jednom stupnju, u relativno uskom području temperatura (oko $40{ }^{\circ} \mathrm{C}$ ). Početak razgradnje PLA je pri $334{ }^{\circ} \mathrm{C}$, s temperaturom maksimalne brzine razgradnje pri $367^{\circ} \mathrm{C}$, uz gubitak mase od 98,6\%, koji se pripisuje cijepanju krajnjih usporednih lanaca makromolekula PLA.

Razgradnja termoplastičnog škroba, TPS $_{30}$ i TPS $_{40}$ odvija se u jednom stupnju (slika 6). Iz TG krivulja termoplastičnog škroba, $\mathrm{TPS}_{30}$ i $\mathrm{TPS}_{40}$ vidljiv je izražen gubitak mase do 
$250^{\circ} \mathrm{C}$. Početni gubitak mase odnosi se na vezanu vodu unutar TPS-a zbog iznimno hidrofilnog karaktera TPS-a (isparavanje slobodne vode događa se pri temperaturama od 90 do $100{ }^{\circ} \mathrm{C}$ ), zatim slijedi isparavanje plastifikatora, glicerola, vezane vode i ostalih, prisutnih hlapljivih komponenti unutar TPS-a te slijedi dekompozicija škroba pri temperaturi $>300{ }^{\circ} \mathrm{C}^{28}$ Razgradnja $\mathrm{TPS}_{30}$ počinje pri $279,9{ }^{\circ} \mathrm{C}$, a TPS 40 pri $277,3{ }^{\circ} \mathrm{C}$, što ukazuje na to da dodatak glicerola kao plastifikatora nema značajnog utjecaja na toplinsku stabilnost TPS-a. Budući da razgradnja PLA počinje na višoj temperaturi, to ukazuje na to da je PLA toplinski stabilniji u usporedbi s oba TPS-a. Gubitak mase PLA iznosi 98,6 \%, iz čega možemo zaključiti da se PLA potpuno razgradio, na što ukazuje i ostatak pri $600{ }^{\circ} \mathrm{C}$ u iznosu od neznatnih $0,8 \%$. Ostatak pri $600{ }^{\circ} \mathrm{C}$ kod TPS-a je značajniji u usporedbi s potpuno razgrađenim PLA, za TPS 30 iznosi $6,7 \%$, a za $\operatorname{TPS}_{40}$ 7,3 \% što se može pripisati mogućem nastajanju umreženja prilikom razgradnje škroba. Na slikama 7-10 prikazane su TG i DTG krivulje PLA/TPSa različitog udjela PLA i TPS-a, s udjelom glicerola od $30 \mathrm{i}$ 40 mas. \% kao plastifikatora. Početak razgradnje $\left(T_{\text {poč }}\right)$ ispitanih mješavina je na temperaturama koje su između temperatura početka razgradnje čistih polimera, PLA te TPS $_{30}$, odnosno TPS 40 . Umješavanjem TPS-a u PLA i dalje je vidljiva prisutnost vezane vode, koja isparava, kao i razgradnja plastifikatora koji se oslobađaju do $250{ }^{\circ} \mathrm{C}$. Na osnovi početne temperature razgradnje $\left(T_{\text {poč. }}\right)$ najbolja toplinska postojanost mješavina PLA/TPS dobivena je dodatkom 40 mas. \% oba TPS-a, odnosno gdje je PLA matrica.

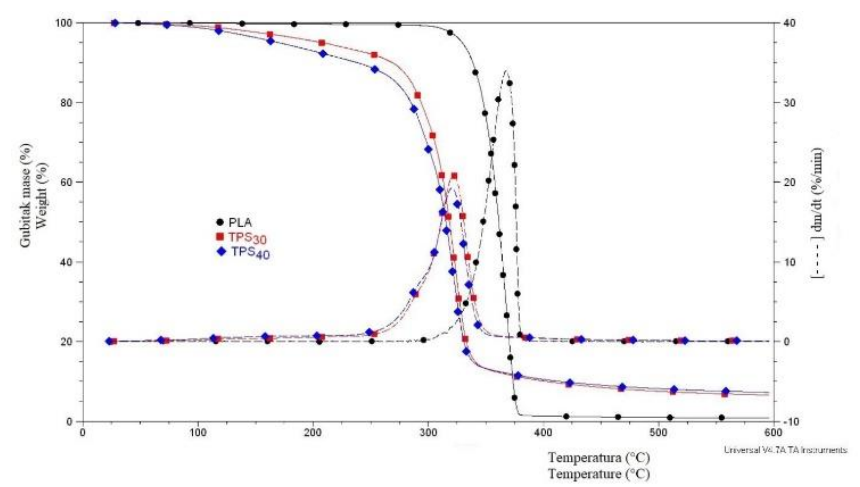

Slika 6 - TG/DTG krivulje čistih polimera

Fig. 6 - TG/DTG curves of pure polymers

Vidljivo je da dodatak PLA pridonosi toplinskoj stabilnosti termoplastičnog škroba uz značajni porast početne temperature razgradnje i do $47^{\circ} \mathrm{C}$. Iz TG i DTG krivulja ispitivanih mješavina PLA/TPS vidljivo je da se mješavine razgrađuju u dva stupnja (dva pika na DTG krivuljama; slike 710), prvi stupanj vezan je za razgradnju TPS-a jer njegova razgradnja započinje pri nižoj temperaturi dok je drugi stupanj razgradnje vezan za razgradnju PLA unutar mješavine.
Temperatura pri maksimalnoj brzini razgradnje PLA u mješavinama je pri višim temperaturama u usporedbi s temperaturom pri maksimalnoj brzini razgradnje čistog PLA, što je povezano s mnogo kompleksnijom prirodom TPS-a unutar mješavine, njegovom sposobnosti ostvarivanja interakcija s matricom PLA što pridonosi mješljivosti PLA i TPS-a. ${ }^{3,7,28}$ Također je temperatura pri maksimalnoj brzini razgradnje TPS-a (40 mas. \%) u mješavinama PLA/TPS porasla za oko $20^{\circ} \mathrm{C}$ povećanjem udjela TPS-a, dok daljnjim povećanjem udjela TPS-a u mješavinama PLA/TPS dolazi do sniženja temperature pri maksimalnoj brzini razgradnje, no i dalje rastu u usporedbi s čistim TPS-om. Interval razgradnje kod mješavina je proširen, što ukazuje na sporiju razgradnju mješavina u usporedbi s čistim polimerima te je izraženiji s većim udjelom TPS-a. Smanjenjem udjela PLA u mješavinama linearno se smanjuje gubitak mase u prvom stupnju razgradnje, $\Delta m_{1}$, koji odgovara temperaturnom području razgradnje TPS-a. Istodobno se linearno povećava gubitak mase u drugom stupnju razgradnje, $\Delta m_{2}$, koji odgovara temperaturnom području razgradnje PLA. Vidljivo je da se gubitci mase $\Delta m_{1}$ i $\Delta m_{2}$ mijenjaju po zakonu aditivnosti, a uočene razlike su u granicama eksperimentalne pogreške. Vrijednosti ostatka pri $600{ }^{\circ} \mathrm{C}$ (nakon razgradnje) ispitivanih mješavina rastu $\mathrm{s}$ porastom udjela TPS-a, što ukazuje na postojanje interakcija između komponenata mješavine i razgradnih produkata.

\subsection{Apsorpcija vode, AV}

Prema literaturi, jedan od velikih nedostataka škroba je njegova izrazita osjetljivost na vodu, odnosno njegov hidrofilni karakter. ${ }^{7-12}$ Materijali od termoplastičnog škroba u prisutnosti vode izrazito bubre, što ima posljedicu raspad materijala. $\mathrm{S}$ druge strane, polilaktid je hidrofobnog karaktera i ima visoku otpornost na vodu. ${ }^{22}$ Stoga je u ovom radu ispitivana apsorpcija vode, moć upijanja vode mješavina PLA/TPS-a te kako udio plastifikatora u termoplastičnom škrobu utječe na apsorpciju vode.

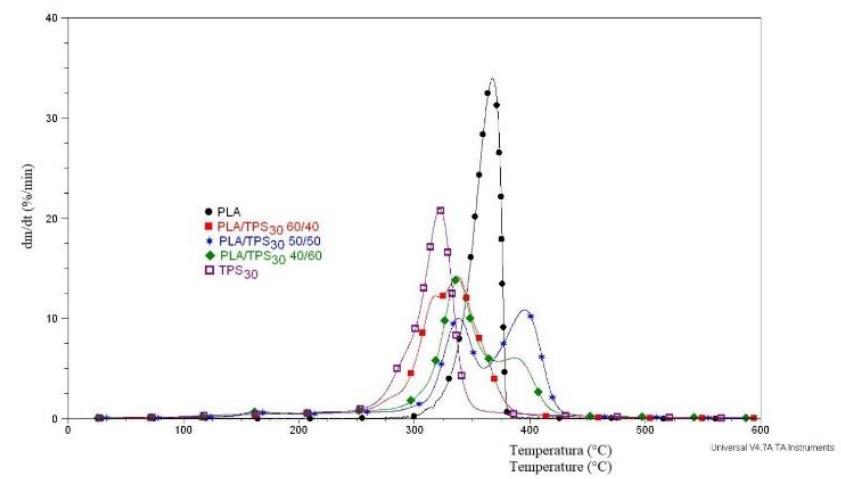

Slika 7 - DTG krivulje čistog PLA i mješavina s TPS $_{30}$

Fig. 7 - DTG curves of pure polymers and their blends with $\mathrm{TPS}_{30}$ 


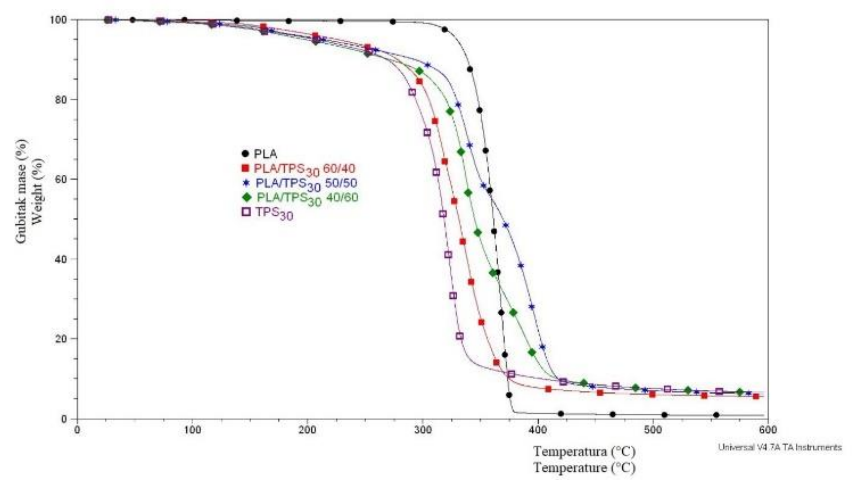

Slika 8 - TG krivulje čistog PLA i mješavina s TPS $_{30}$

Fig. 8 - TG curves of pure polymers and their blends with $\mathrm{TPS}_{30}$

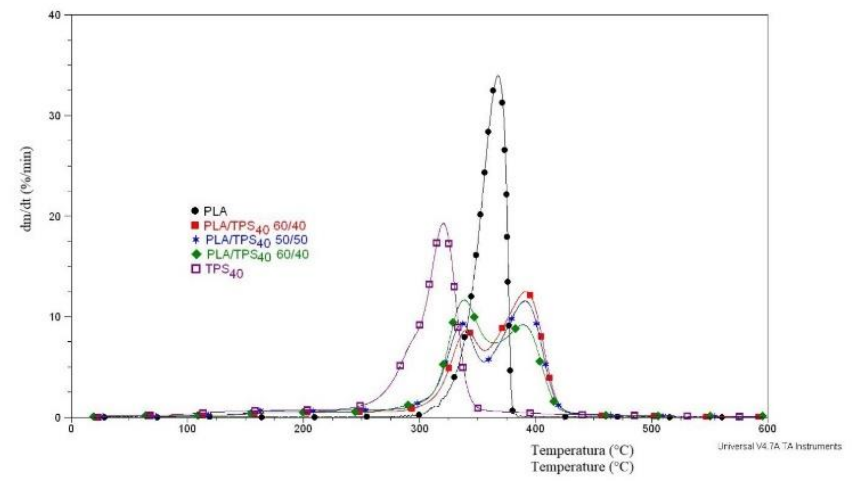

Slika 9 - DTG krivulje čistog PLA i mješavina s TPS $_{40}$

Fig. 9 - DTG curves of pure polymers and their blends with TPS $_{40}$

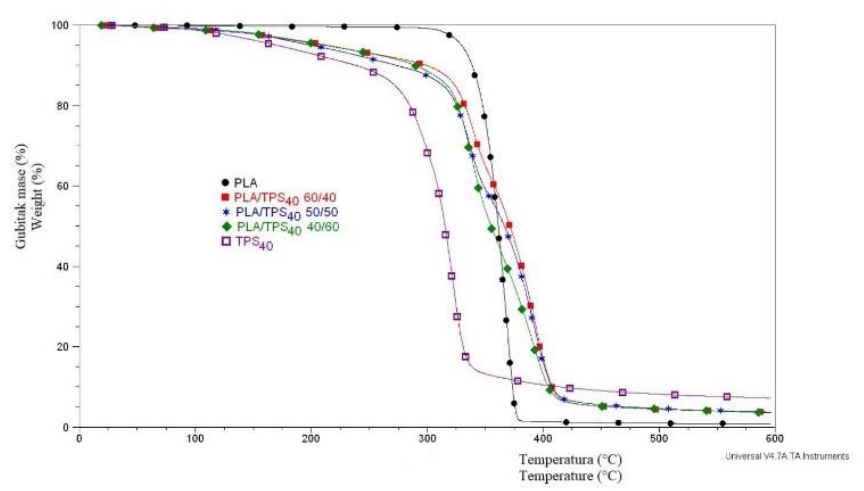

Slika 10 - TG krivulje čistog PLA i mješavina s TPS $_{40}$

Fig. 10 - TG curves of pure polymers and their blends with $\mathrm{TPS}_{40}$

Apsorpcija vode pratila se promjenom mase tijekom 5 dana pri temperaturi od $25{ }^{\circ} \mathrm{C}$. Rezultati promjene mase tijekom 5 dana (mjerena svaka 24 h) prikazani su tablici 4. Na slici 11 prikazan je grafički prikaz ovisnosti apsorpcije vode o vremenu uranjanja (tijekom 5 dana) za sve ispitivane mješavine PLA/TPS-a. Određena je AV i za čisti PLA kao i TPS 30 i TPS 40 . Čisti PLA, kao što se moglo očekivati, tijekom 5 dana nije pokazao promjenu mase, što je upravo potvrdilo njegov hidrofobni karakter. TPS $_{30}$ i TPS $_{40}$ već su
Tablica 3 - Rezultati termogravimetrijske analize

Table 3 - Results of thermogravimetric analysis

\begin{tabular}{|c|c|c|c|c|c|c|c|c|}
\hline $\begin{array}{l}\text { Uzorak } \\
\text { Sample }\end{array}$ & $\begin{array}{c}T_{\text {poč. }} \\
/{ }^{\circ} \mathrm{C} \\
T_{\text {ons. }} / \\
{ }^{\circ} \mathrm{C}\end{array}$ & $\begin{array}{l}T_{1} \text { max } \\
/{ }^{\circ} \mathrm{C}\end{array}$ & $\begin{array}{l}\Delta m_{1} \\
/ \%\end{array}$ & $\begin{array}{l}T_{2}{ }^{\max } \\
/{ }^{\circ} \mathrm{C}\end{array}$ & $\begin{array}{c}\Delta \mathrm{m}_{2} / \\
\%\end{array}$ & $\begin{array}{c}T_{\text {kraj }} / \\
{ }^{\circ} \mathrm{C} \\
T_{\text {end }} / \\
{ }^{\circ} \mathrm{C}\end{array}$ & $\begin{array}{l}\Delta T \\
/{ }^{\circ} \mathrm{C}\end{array}$ & $\begin{array}{c}R_{600^{\circ} \mathrm{C}} \\
/ \%\end{array}$ \\
\hline PLA & 334 & - & - & 367 & 98,6 & 376 & 42 & 0,8 \\
\hline $\mathrm{TPS}_{30}$ & 280 & 323 & 85,9 & - & - & 335 & 55 & 6,7 \\
\hline $\mathrm{TPS}_{40}$ & 277 & 322 & 79,3 & - & - & 333 & 56 & 7,3 \\
\hline $\begin{array}{l}\mathrm{PLA} / T P S_{30} \\
60 / 40\end{array}$ & 325 & 343 & 34,1 & 388 & 55,8 & 405 & 80 & 2,9 \\
\hline $\begin{array}{l}{\mathrm{PLA} / \mathrm{TPS}_{40}}_{4} \\
60 / 40\end{array}$ & 322 & 338 & 37,7 & 390 & 57,5 & 411 & 90 & 3,6 \\
\hline $\begin{array}{l}\mathrm{PLA} / \mathrm{TPS}_{30} \\
50 / 50\end{array}$ & 319 & 339 & 44,0 & 396 & 48,2 & 412 & 93 & 6,3 \\
\hline $\begin{array}{l}\text { PLA/TPS } \\
50 / 50\end{array}$ & 317 & 337 & 43,1 & 392 & 50,7 & 412 & 95 & 3,8 \\
\hline
\end{tabular}

tijekom prvog dana znatno apsorbirali vodu, vrijednost AV za $\mathrm{TPS}_{30}$ iznosi 104,9\%, dok za TPS 40 59,2\% (tablica 4). Nakon 2 dana došlo je do raspada ispitivanih uzoraka $\mathrm{TPS}_{30}$ i TPS $_{40}$, što je onemogućilo daljnje praćenje promjene mase. Zbog jasnijeg prikaza rezultata na slici 11 prikazani su samo rezultati apsorpcije vode mješavina PLA/TPS.

Mješavine PLA/TPS-a su tijekom prvog dana apsorbirale najveću količinu vode od 7 do $26 \%$. Može se primijetiti da je već tijekom prvog dana ispitivanja došlo do znatne apsorpcije vode, zatim dolazi do usporavanja AV te konačnu konstantnu vrijednost za većinu ispitivanih mješavina dostiže treći dan ispitivanja. Uravnotežena vrijednost smatra se maksimalnom vrijednosti apsorpcije vode za ispitivane mješavine. Poznato je da su materijali poput škroba upravo odgovorni za osjetljivost uzorka na apsorpciju vode. ${ }^{28}$ Općenito, apsorpcija vode za polimerne mješavine ovisna je o težoj molekulskoj frakciji (TPS u ovom istraživanju), udjelu hidrofobnog polimera (PLA), termodinamičkoj interakcijskoj energiji između TPS-a i hidrofobnog polimera i njihovim difuzijskim koeficijentima. ${ }^{30}$ Škrob kao hidrofilni polimer olakšava prodiranje vode u uzorke stvaranjem vodikove veze između vode i njegove hidroksilne skupine.

Može se očekivati da povećanjem udjela TPS-a apsorpcija vode raste u svim ispitanim mješavinama, odnosno kapacitet apsorpcije vode ovisan je o sadržaju TPS-a. Na slici 11 vidljivo je da je kod nižeg sadržaja TPS-a apsorpcija vode nešto sporija, dok se kod višeg udjela TPS-a apsorpcija vode izrazito ubrzava. Prema literaturi, u dvofaznim mješavinama PLA/TPS-a kod manjeg udjela TPS-a, TPS djeluje 
kao punilo u kontinuiranoj matrici PLA. PLA formira vrlo dobru kontinuiranu fazu koja pokriva TPS i onemogućava TPS-u znatnu apsorpciju vode. ${ }^{31,32}$ Kod većeg sadržaja TPSa, gdje PLA postaje diskontinuirana faza, raste i broj šupljina unutar takve mješavine. Voda lakše i brže prolazi kroz šupljine mješavine i biva apsorbirana TPS-om, što ima za posljedicu povećanje apsorpcije vode. Usporedbom rezultata AV mješavina istog sastava, a različitog udjela plastifikatora TPS-a $\left(\right.$ TPS $_{30}$ i TPS $_{40}$ ) vidljivo je da TPS s većim udjelom glicerola (40 mas. \%) pokazuje niže vrijednosti apsorpcije vode. Veći udio plastifikatora pridonosi boljoj homogenosti TPS-a, stvarajući manji broj šupljina unutar strukture i time omogućuje manju apsorpciju vode unutar mješavina.

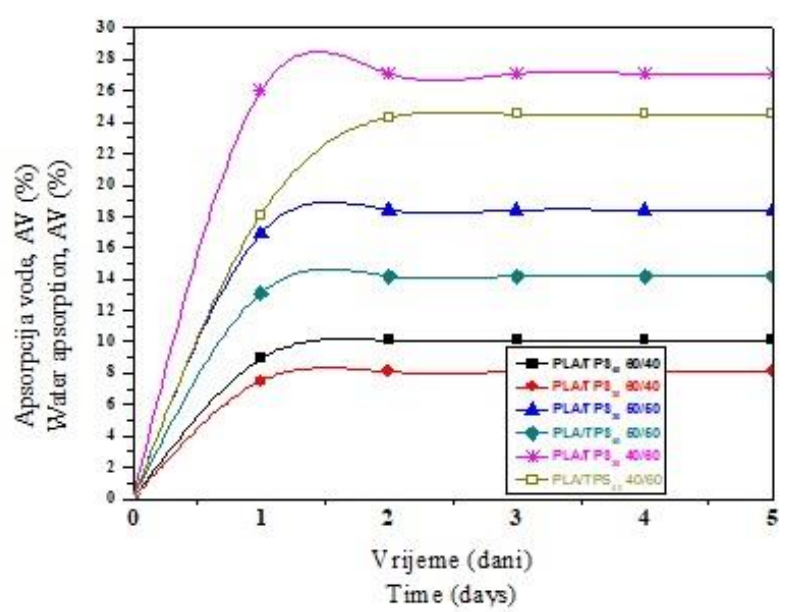

Slika 11 - Apsorpcija vode ispitivanih mješavina Fig. 11 - Water absorption of investigated samples

Tablica 4 - Promjena mase tijekom pet dana

Table 4 - Change of mass during five days

\begin{tabular}{l|c|c|c|c|c|c|c|c|c|c|c}
\hline $\begin{array}{l}\text { Uzorak } \\
\text { Sample }\end{array}$ & $m_{0} / \mathrm{g}$ & $m_{1} / \mathrm{g}$ & $A v_{1} / \%$ & $m_{2} / \mathrm{g}$ & $A v_{2} / \%$ & $m_{3} / \mathrm{g}$ & $A v_{3} / \%$ & $\mathrm{~m}_{4} / \mathrm{g}$ & $A v_{4} / \%$ & $m_{5} / \mathrm{g}$ & $A v_{5} / \%$ \\
\hline PLA & 0,279 & 0,279 & 0,0 & 0,279 & 0,0 & 0,279 & 0,0 & 0,279 & 0,0 & 0,279 & 0,0 \\
$\mathrm{TPS}_{30}$ & 0,423 & 0,867 & 104,9 & - & - & - & - & - & - & - & - \\
PPS $_{40}$ & 0,255 & 0,406 & 59,2 & - & - & - & - & - & - & - & - \\
PLA/TPS $_{30} 60 / 40$ & 0,293 & 0,260 & 8,9 & 0,263 & 10,1 & 0,263 & 10,1 & 0,263 & 10,1 & 0,263 & 10,1 \\
PLA/TPS $_{40} 60 / 40$ & 0,205 & 0,205 & 7,5 & 0,220 & 8,1 & 0,222 & 8,1 & 0,222 & 8,1 & 0,222 & 8,1 \\
PLA/TPS $_{30} 50 / 50$ & 0,268 & 0,314 & 16,9 & 0,317 & 18,4 & 0,317 & 18,4 & 0,317 & 18,4 & 0,317 & 18,4 \\
PLA/TPS $_{40} 50 / 50$ & 0,271 & 0,307 & 13,1 & 0,309 & 14,2 & 0,309 & 14,2 & 0,309 & 14,2 & 0,309 & 14,2 \\
PLA/TPS $_{30} 40 / 60$ & 0,239 & 0,301 & 26,0 & 0,304 & 27,1 & 0,304 & 27,1 & 0,304 & 27,1 & 0,304 & 27,1 \\
PLA/TPS $_{40} 40 / 60$ & 0,266 & 0,226 & 18,1 & 0,281 & 24,3 & 0,281 & 24,5 & 0,281 & 24,5 & 0,281 & 24,5 \\
\hline
\end{tabular}

\section{Zaključak}

Dodatkom TPS-a u PLA dolazi do porasta stupnja kristalnosti PLA, odnosno TPS potiče hladnu kristalizaciju, povećava kristalizaciju PLA te je omogućeno pravilnije slaganje lanaca polilaktida u kristalnoj strukturi. Rezultati TGA analize ukazuju da dodatak PLA TPS-u doprinosi znatnom povećanju toplinske postojanosti TPS-a. PLA se potpuno razgrađuje pri $600{ }^{\circ} \mathrm{C}$, dok je kod TPS-a prisutan ostatak koji je posljedica umreženja prilikom razgradnje škroba ili prisutnosti anorganskih nečistoća u TPS-u. Ispitivanjem apsorpcije vode uočeno je da PLA ne apsorbira vodu, što potvrđuje njegov hidrofobni karakter. Za razliku od PLA, TPS ima izrazito hidrofilan karakter. Povećanje udjela TPS-a u mješavinama PLA/TPS pokazuje više vrijednosti apsorpcije vode. Utjecaj glicerola kao plastifikatora TPS-a nema značajnu ulogu u ispitivanju toplinskih svojstava, dok je ispitivanje apsorpcije vode pokazalo da veći udio glicerola ima niže vrijednosti apsorpcije vode.

\section{Popis kratica i simbola}

\section{List of abbreviations and symbols}

$\begin{array}{ll}\text { PLA } & \text { - polilaktid } \\ & \text { - polylactide } \\ \text { TPS }_{30} & \text { - termoplastični škrob (30 mas \% glicerola) } \\ & \text { - thermoplastic starch (30 wt \% glycerol) } \\ \text { TPS }_{40} & - \text { termoplastični škrob (40 mas \% glicerola) } \\ & \text { - thermoplastic starch (40 wt \% glycerol) } \\ \text { PLLA } & \text { - poli (L-laktid) } \\ & \text { - poly(L-lactide) } \\ \text { PDLA } & \text { - poli (D-laktid) } \\ & \text { - poly(DLA-lactide) } \\ \text { PDLLA } & \text { - poli (DL-laktid) } \\ & - \text { poly(DL-lactide) } \\ \text { PHA } & - \text { poli (hidroksi-alkanoati) } \\ & \text { - polyhydroxyalkanoate } \\ \text { PEG } & - \text { poli (etilen glikol) } \\ & - \text { poly(ethylene glycol) }\end{array}$




\begin{tabular}{|c|c|}
\hline PCL & - polikaprolakton \\
\hline & - polycaprolactone \\
\hline AV & - apsorpcija vode \\
\hline & - water absorption \\
\hline$m_{0}$ & - početna masa, g \\
\hline & - initial mass, $g$ \\
\hline$m_{1}$ & - masa nakon prvog dana bubrenja, g \\
\hline & - mass after the first day of swelling, $g$ \\
\hline DSC & - diferencijalna pretražna kalorimetrija \\
\hline & - differential scanning calorimetry \\
\hline$\Delta H_{\mathrm{cc}}$ & $\begin{array}{l}\text { - entalpija hladne kristalizacije } \\
\text { tijekom zagrijavanja, J g }\end{array}$ \\
\hline & - cold crystallization enthalpy during heating, $\mathrm{Jg}^{-1}$ \\
\hline$\Delta H_{\mathrm{m}}$ & - entalpija taljenja tijekom zagrijavanja, J g-1 \\
\hline & - melting enthalpy during heating, $\mathrm{Jg}^{-1}$ \\
\hline$T_{\mathrm{g}}$ & - temperatura staklastog prijelaza \\
\hline & - glass transition temperature \\
\hline$T_{\mathrm{CC}}$ & - temperatura kristalizacije tijekom hlađenja, ${ }^{\circ} \mathrm{C}$ \\
\hline & - crystallization temperature during cooling, ${ }^{\circ} \mathrm{C}$ \\
\hline$T_{\mathrm{cc}}$ & $\begin{array}{l}\text { - temperatura hladne kristalizacije } \\
\text { tijekom zagrijavanja, }{ }^{\circ} \mathrm{C}\end{array}$ \\
\hline & - cold crystallization temperature during heating, ${ }^{\circ} \mathrm{C}$ \\
\hline TGA & - termogravimetrijska analiza \\
\hline & - thermogravimetric analysis \\
\hline TG & - termogravimetrijska krivulja \\
\hline & - termogravimetric curve \\
\hline DTG & - derivacijska krivulja \\
\hline & - derivative curve \\
\hline$T_{\text {poč. }}$ & - temperatura početka razgradnje, ${ }^{\circ} \mathrm{C}$ \\
\hline & - initial degradation temperature, $T_{\text {ons. }}{ }^{\circ} \mathrm{C}$ \\
\hline$T_{\text {kraj }}$ & - temperatura kraja razgradnje, ${ }^{\circ} \mathrm{C}$ \\
\hline & - final degradation temperature, $T_{\text {end }}{ }^{\circ} \mathrm{C}$ \\
\hline$T_{\max }$ & - temperatura pri maksimalnoj brzini razgradnje, ${ }^{\circ} \mathrm{C}$ \\
\hline & - maximum loss rate temperatures, ${ }^{\circ} \mathrm{C}$ \\
\hline$\Delta m$ & - gubitak mase, g \\
\hline & - weight loss, g \\
\hline$\Delta T$ & - temperaturno područje razgradnje, ${ }^{\circ} \mathrm{C}$ \\
\hline & - temperature degradation range \\
\hline$R_{600^{\circ} \mathrm{C}}$ & - ostatak pri $600{ }^{\circ} \mathrm{C}, \%$ \\
\hline & - residue at $600{ }^{\circ} \mathrm{C}, \%$ \\
\hline
\end{tabular}

\section{Literatura}

\section{References}

1. C.-C. Chen, J.-Y. Chueh, H. Tseng, H.-M. Huang, S.-Y. Lee, Preparation and characterization of biodegradable PLA polymeric blends, Biomaterials 24 (2003) 1167-1173, doi: https://doi.org/10.1016/S0142-9612(02)00466-0.

2. G. E. Luckachan, C. K. S. Pillai, Biodegradable Polymers - A Review on Recent Trends and Emerging Perspectives, J. Polym. Environ. 19 (2011) 637-676, doi: https://doi.org/10.1007/s10924-011-0317-1.

3. D. Garlotta, A Literature Review of Poly(Lactic Acid), J. Polym. Environ. 9 (2001) 63-84, doi: https://doi.org/10.1023/A:1020200822435.
4. J.-B. Zeng, K.-A. Li, A.-K. Du, Compatibilization strategies in poly(lactic acid)-based blends, RSC Adv. 5 (2015) 3254632565, doi: https://doi.org/10.1039/c5ra01655j.

5. R. Auras, B. Harte, S. Selke, An overview of polylactides as packaging materials. Macromol. Biosci. 4 (2004) 835-864, doi: https://doi.org/10.1002/mabi.200400043.

6. K. M. Nampoothiri, N. R. Nair, R. P. John, An overview of the recent developments in polylactide (PLA) research, Bioresour. Techn. 101 (2010) 8493-8501, doi: https://doi.org/10.1016/j.biortech.2010.05.092.

7. V. B. Carmona, A. C. Corrêa, J. M. Marconcini, Properties of a Biodegradable Ternary Blend of Thermoplastic Starch (TPS), Poly( $\varepsilon$-Caprolactone) (PCL) and Poly(Lactic Acid) (PLA), J. Polym. Environ. 23 (2015) 83-89, doi: https://doi.org/10.1007/s10924-014-0666-7.

8. S. Lai, T. Don, Y. Huang, Preparation and Properties of Biodegradable Thermoplastic Starch/ Poly(hydroxyl butyrate) Blends, J. Appl. Polym. Sci. 100 (2006) 2371-2379, doi: https://doi.org/10.1002/app.23085.

9. J. Guan, K. Eskridge, M. Hanna, Acetylated starch-polylactic acid loose-fill packaging materials, Ind. Crop. Prod. 22 (2004) 109-123, doi: https://doi.org/10.1016/j.indcrop.2004.06.004.

10. R. Shanks, I. Kong, Thermoplastic Starch, Thermoplastic Elastomers, u A. El-Sonbati (ur.), Vol. 6, InTech, Croatia, 2012., str. 95-116.

11. B. Ghanbarzadeh, H. Almasi, Biodegradable Polymers, in R. Chamy and F. Rosenkranz (ur.), Biodegradation - Life of Science, Vol. 6, InTech, Croatia, 2013., str. 141-185.

12. P. J. White, A. Tziotis, New corn starches, in A. C. Eliasson (ur.), Starch in food: Structure, function and applications, Vol. 10, Woodhead Publ. Lim., Cambridge, 2004., str. 307-632.

13. T. Tábi, J. G. Kovács, Examination of injected moulded thermoplastic maize starch, eXPRESS Polym. Lett. 12 (2007) 804809, doi: https://doi.org/10.3144/expresspolymlett.2007.111.

14. T. Tábi, F. Tuba, L. Oláh, Investigation of time-dependent behaviour of starch-based, injection molded biodegradable polymer, Mater. Sci. Forum 589 (2008) 281-286, doi: https://doi.org/10.4028/www.scientific.net/MSF.589.281.

15. E. W Fischer, H. J. Sterzel, G. Wegner, Investigation of the structure of solution grown crystals of lactide copolymers by means of chemical reaction, Kolloid-Z.u.Z.Polymere 251 (1973) 980-990, doi: https://doi.org/10.1007/BF01498927.

16. S. Lučić Blagojević, M. Zeljko, A. Pustak, Utjecaj modifikacije višestjenih ugljikovih nanocjevčica na svojstva poliuretana: I. Morfologija i toplinska svojstva, Kem. Ind. 66 (2017) 119128, doi: http://doi.org/10.15255/KUI.2016.044.

17. K. Fukushima, A. Fina, F. Geobaldo, A. Venturello, G. Camino, Properties of poly(lactic acid) nanocomposites based on montmorillonite, sepiolite and zirconium phosphonate, eXPRESS Polym. Lett. 6 (2012) 914-926, doi: https://doi.org/10.3144/expresspolymlett.2012.97.

18. M. A. Huneault, H. Li, Morphology and properties of compatibilized polylactide/thermoplastic starch blends, Polymer 28 (2007) 270-280, doi: https://doi.org/10.1016/j.polymer.2006.11.023.

19. D. J. Plackett, Maleated Polylactide as an Interfacial Compatibilizer in Biocomposites, J. Polym. Environ. 12 (2004) 131138, doi: https://doi.org/10.1023/B:JOOE.0000038544.75554.0e. 
20. J. P. Kalish, K. Aou, X. Yang, S. L. S. Hsu, Spectroscopic and thermal analyses of $\alpha^{\prime}$ and $\alpha$ crystalline forms of poly(l-lactic acid), Polymer 52 (2011) 814-821, doi: https://doi.org/10.1016/j.polymer.2010.12.042.

21. S. A. Nezamzadeh, Z. Ahmadi, F. A. Taromi, From microstructure to mechanical properties of compatibilized polylactide/thermoplastic starch blends; J. Appl. Polym. Sci. 134 (2017) 1-9, doi: https://doi.org/10.1002/APP.44734.

22. K. Fukushima, D. Tabuani, C. Abbate, M. Arena, P. Rizzarelli, Preparation, Characterization and biodegradation of biopolymer nanocomposites based on fumed silica, Eu. Polym. J. 47 (2011) 139-152, doi: https://doi.org/10.1016/j.eurpolymj.2010.10.027.

23. V. Mittal, T. Akhtar, N. Matsko, Mechanical, thermal, rheological and morphological properties of binary and ternary blends of PLA, TPS and PCL, Macromol. Mater. Eng. 300 (2015) 423-435,

doi: https://doi.org/10.1002/mame.201400332.

24. H.-T. Liao, C.-S. Wu, Preparation and characterization of ternary blends composed of polylactide, poly(e-caprolactone) and starch, Mater. Sci. Eng. A. 515 (2009) 207-214, doi: https://doi.org/10.1016/j.msea.2009.03.003.

25. M. E. Broz, D. L. Vander Hart, N. R. Washburn, Structure and mechanical properties of poly(D,L-lactic acid)/poly( $\varepsilon$-caprolactone) blend, Biomaterials 24 (2003) 4181-4190, doi: https://doi.org/10.1016/S0142-9612(03)00314-4.

26. E. de M. Teixeira, A. A. S.Curvelo, A. C. Corrêa, J. M. Marconcini, G. M.Glenn, L. H. C. Mattoso, Properties of thermoplastic starch from cassava bagasse and cassava starch and their blends with poly (lactic acid), Ind. Crop. Prod. 37 (2012) 61-68,

doi: https://doi.org/10.1016/j.indcrop.2011.11.036.

27. J. Zhang, J. Lou, S. Ilias, P. Krishnamachari, J. Yan, Thermal properties of poly(lactic acid) fumed silica nanocomposites: experiments and molecular dynamics simulations, Polymer 49 (2008) 2381-2386, doi: https://doi.org/10.1016/j.polymer.2008.02.048.

28. T. Ke, X. Sun, Physical properties of poly(lactic acid) and starch composites with various blending ratios, Cereal. Chem. 77 (2000) 761-768, doi: http://doi.org/10.1094/CCHEM.2000.77.6.761.

29. Y. Zhang, C. B. Rempel, Retrogradation and Antiplasticization of Thermoplastic Starch, u A. Z. El-Sonbati (ur.), Thermoplastic Elastomers, Vol. 7, InTech, Croatia, 2012., str. 117134.

30. Y. B. Shin, B. H. Jang, B. S. Kim, Thermal, morphological, and mechanical properties of biobased and biodegradable blends of poly(lactic acid) and chemically modified thermoplastic starch, Polym. Eng. Sci. 51 (2011) 826-834, doi: http://doi.org/10.1002/pen.21896.

31. M. Pervaiz, P. Oakley, M. Sain, Development of Novel Waxenabled Thermoplastic Starch Blends and Their Morphological, Thermal and Environmental Properties, Int. J. Compost. Mater. 4 (2014) 204-212, doi: http://doi.org/10.5923/j.cmaterials.20140405.02.

32. O. Martin, L. Avérous, Poly(lactic acid): plasticization and properties of biodegradable multiphase systems, Polymer 42 (2001) 6209-6219, doi: https://doi.org/10.1016/S0032-3861(01)00086-6.

\title{
SUMMARY
}

\author{
Thermal Properties of Biodegradable PLA/TPS Blends \\ Vesna Ocelić Bulatović,a* Emi Govorčin Bajsić, Dajana Kučić Grgić, and Antun Jozinovićb
}

In this paper, thermal properties of polylactide (PLA) and thermoplastic starch (TPS) blends with different proportions of TPS were investigated. TPS at different ratios of glycerol (30 and 40 wt. \%) as a plasticizer, were prepared. To gain an insight into the hydrophilic/hydrophobic character of the PLA/TPS blends, water absorption was performed. The results of thermal properties indicated that TPS enhanced the cold crystallization process of polylactide due to the nucleation effect of TPS. TPS increases the ability of the PLA crystallization and provides a more accurate alignment of polylactide chains in the crystal structure. The effect of glycerol as a TPS plasticizer has no significant role in the thermal properties, while water absorption testing has shown that with higher glycerol content as TPS plasticizers, lower water absorption values of PLA/TPS blend are obtained.

\section{Keywords}

Polylactide, thermoplastic starch, plastification, glycerol, thermal properties, water absorption

\footnotetext{
a University of Zagreb

Faculty of Chemical Engineering and Technology

Marulićev trg 19,10 000 Zagreb, Croatia

b Josip Juraj Strossmayer University of Osijek

Faculty of Food Technology Osijek

Franje Kuhača 20, 31000 Osijek, Croatia
}

Received April 10, 2018

Accepted June 27, 2018 